\title{
PERLINDUNGAN HUKUM BAGI KREDITUR BANK PADA PERJANJIAN KAWIN DALAM PERKAWINAN CAMPURAN
}

\author{
Kadek Megah Bintaranny, I Nyoman Putu Budiartha, I Wayan Arthanaya \\ Fakultas Hukum Universitas Warmadewa, Denpasar - Bali, Indonesia \\ megahasia13@yahoo.com
}

\begin{abstract}
Abstrak
Problematika yang dihadapi pelaku of perkawinan campuran di Indonesia adalah adanya ketentuan dalam hukum Indonesia mengenai penyatuan harta kekayaan secara serta-merta menjadi harta bersama setelah adanya perkawinan tersebut. Namun di sisi lain, terdapat aturan perundang-undangan yang mengatur bahwa orang asing tidak dapat memiliki hak milik atas properti di Indonesia, sehingga harta bersama yang melibatkan sejumlah properti dalam bentuk benda bergerak maupun tidak bergerak akan mustahil untuk dimiliki oleh orang asing tersebut. Penelitian ini menelaah dua hal: perlindungan hukum bagi pihak ketiga, yaitu kreditur bank berkaitan dengan kedudukan/status harta benda pasangan suami-istri dalam perkawinan campuran dalam perjanjian kawin dan akibat hukum kredit bermasalah terkait dengan harta benda pasangan tersebut apabila mereka melakukan wanprestasi. Untuk mengungkap dua hal ini, penelitian dilakukan menggunakan metode penelitian hukum normatif. Hasil menunjukkan pihak kreditur dilindungi secara preventif dan represif. Akibat hukum bagi harta benda suami atau istri untuk kreditur bank apabila debitur yang terikat dalam perkawinan campuran tersebut wanprestasi tergantung dari bentuk perjanjian kawin yang dibuat. Suami atau isteri yang berkewarganegaraan Indonesia sebagai debitur dapat memberi jaminan kebendaan dari harta kekayaannya secara bebas dan dapat diambil sebagai jaminan pelunasan oleh pihak kreditur bank apabila debitur tersebut wanprestasi.
\end{abstract}

Kata Kunci: Perkawinan Campuran; Perjanjian Kawin; Perlindungan Hukum Kreditur

\begin{abstract}
The problem faced by the couple of a mixed marriage in Indonesia is that there are provisions in Indonesian law regarding the incorporating of assets immediately into joint property after the marriage. But on the other hand, there are laws regulating that foreigners may not own property rights in Indonesia, so joint property involving a number of properties in the form of movable or immovable property will be impossible for foreigners to own. This study examines two issues: the legal protection for third party, the bank creditors relating to the status/property status of a married couple in mixed marriages in a marriage agreement and the legal consequences of non-performing loans related to the couple's property if they commit defaults. To uncover these two matters, the study was conducted using the normative legal research method. The results show that creditors are protected in a preventive and repressive manner. Legal consequences for husband or wife property for bank creditors if the debtor is bound in the mixed marriage defaults depend on the form of the marriage agreement made. A husband or wife who is an Indonesian citizen as a debtor is permitted to guarantee the material security of his assets freely and can be taken as collateral for repayment by the bank's creditors if the debtor is in default.
\end{abstract}

Keywords: Mixed Marriage; Marriage Agreement; Legal Protection for Creditor

\section{PENDAHULUAN}

Surat Permohonan yang diajukan Nyonya Ike Farida tertanggal 11 Mei 2015 menjadi sebuah solusi baru di Indonesia bagi pasangan suami isteri dalam perkawinan campuran namun belum membuat Perjanjian Kawin sebelum perkawinan berlangsung. Putusan Mahkamah Konstitusi Nomor 69/PUU- XII/2015 telah membuka kesempatan untuk membuat perjanjian kawin, tidak hanya sebelum perkawinan terjadi tetapi juga dapat dilakukan pada saat perkawinan berlangsung (Hariss \& Kasmara, 2019). Sebelum adanya Putusan Mahkamah Konstitusi Nomor 69/PUU-XII/2015 ini, warga negara Indonesia (WNI) dapat kehilangan hak tertinggi dan terpenuhinya sebagai WNI, yaitu hak memiliki properti di Indonesia apabila tidak membuat perjanjian kawin dalam jangka waktu tertentu. Perjanjian 
kawin tidak lagi dianggap sebagai pengikat hubungan kontrak tetapi adanya tujuan yang lebih penting yaitu melindungi hak-hak dan kewajiban para pihak dalam perkawinan tersebut termasuk status harta kekayaan yang dimiliki masing-masing.

Klausul terpenting dalam Perjanjian Perkawinan adalah mengenai pemisahaan harta, dimana dalam perjanjian kawin secara jelas dan tegas memisahkan harta masing-masing suami dan isteri, sehingga tidak terjadi suatu percampuran harta bersama yang dapat berakibat kepada hilangnya hak untuk dapat memiliki tanah ataupun properti di Indonesia selain dari Hak Pakai yang terbatas jangka waktunya. Namun di sisi lain, hal ini pastinya akan memberikan efek samping terhadap pihak ketiga, yaitu kreditur bank. Kreditur bank itu sendiri merupakan pihak yang memberikan suatu pinjaman kepada pihak kedua dengan suatu jaminan tertentu. Yang dimaksud pihak kedua di sini adalah sebagai peminjam atau yang berhutang atau disebut debitur.Dalam kasus ini, seorang WNI dapat bertindak sebagai debitur yang memungkinkannya untuk melakukan transaksi dengan kreditur dengan suatu jaminan kepemilikan propertinya di masa yang akan datang. Oleh karena itu, perlu adanya pengaturan yang jelas di dalam isi perjanjian mengenai perlindungan hukum, tidak hanya bagi kedua pihak dalam perkawinan tersebut, tetapi juga bagi pihak ketiga yang dilibatkan dalam suatu kegiatan transaksi dengan salah satu pasangan. Tujuannya adalah apabila terjadi suatu permasalahan di antara suami dan istri, hak-hak dari pihak ketiga tersebut tetap dilindungi dan WNI yang bersangkutan tetap dapat menjalankan kewajibannya dengan tepat.

Perlindungan hukum yang dimaksudkan di sini adalah perlindungan hukum yang diberikan kepada subyek hukum ke dalam bentuk perangkat baik yang bersifat preventif maupun yang bersifat represif, baik yang lisan maupun yang tertulis. Dengan kata lain dapat dikatakan bahwa perlindungan hukum sebagai suatu gambaran tersendiri dari fungsi hukum itu sendiri, yang memiliki konsep bahwa hukum memberikan suatu keadilan, ketertiban, kepastian, kemanfaatan dan kedamaian. Perlindungan hukum preventif merupakan perlindungan hukum yang dilakukan sebelum suatu permasalahan terjadi dan represif merupakan perlindungan hukum yang diberikan karena adanya suatu permasalahan atau sengketa.

Perjanjian kawin itu sendiri memiliki peranan yang sangat penting sebelum kreditur bank memutuskan untuk memberikan pinjaman kepada debitur, terutama setelah adanya Putusan Mahkamah Konstitusi Nomor 69/PUU-XII/2015, yang mana perjanjian kawin dapat dibuat pada saat perkawinan dan dapat dirubah atau dibatalkan, serta menjadi pegangan bagi kreditur apabila adanya wanprestasi dari pihak debitur di kemudian hari yang menyebabkan perjanjian kredit tidak dapat dilanjutkan.

Terkait harta dan perkawinan, sejumlah kajian telah diluncurkan. Kajian tentang pembuatan perjanjian kawin setelah perkawinan dan akibat hukumnya terhadap pihak ketiga telah dikaji dalam sebuah penelitian tesis master (Kusuma, 2010). Perjanjian perkawinan yang dibuat setelah perkawinan berlangsung juga mempunyai akibat hukum dan telah diluncurkan dalam kajian ilmiah (Istrianty \& Priambada, 2015). Implikasi perjanjian kawin terhadap harta dalam perkawinan campur juga telah diungkap dalam kajian ilmiah (Situmeang, 2019). Selain itu, akibat hukum perjanjian harta bersama yang dibuat oleh suami istri setelah perkawinan berdasarkan Putusan Mahkamah Konstitusi Nomor 69/PUU-XIII/2015 juga pernah ditelaah dalam sebuah kajian ilmiah (Hariss \& Kasmara, 2019).

Dari latar belakang masalah tersebut di atas, maka dapatlah diidentifikasikan rumusan masalah sebagai berikut:

a. Bagaimanakah perlindungan hukum bagi pihak ketiga, yaitu kreditur bank berkaitan dengan kedudukan/status harta benda pasangan perkawinan campuran dalam perjanjian kawin.

b. Bagaimanakah akibat hukum kredit bermasalah terkait dengan harta benda suami atau istri bagi kreditur bank apabila debitur yang terikat dalam perkawinan campuran tersebut wanprestasi?

Tujuan penelitian ini adalah untuk mengetahui pengaturan perjanjian perkawinan dalam perkawinan campuran sehingga dapat dilihat perlindungan hukum bagi pihak ketiga yaitu kreditur bank yang berkaitan dengan status harta benda pasangan perkawinan campuran apabila pasangannya sebagai debitur melakukan wanprestasi.

\section{METODE PENELITIAN}

Penulisan ini menggunakan metode normatif dengan melakukan kajian pustaka dari sumber-sumber hukum dalam bentuk undang-undang dan buku-buku teori hukum dengan pendekatan masalah adalah pendekatan perundang- undangan dan konseptual. Bahan hukum yang bersumber dari Undang-undang 
yang digunakan ialah Undang-Undang Nomor 1 Tahun 1974 tentang Perkawinan, Pasal 119 Kitab Undang-Undang Hukum Perdata, Putusan Mahkamah Konstitusi Nomor 69/PUU-XIII/2015, Pasal 31 Peraturan Bank Indonesia Nomor 14/15/PBI/2012, dan Surat Edaran Bank Indonesia Nomor 26/4/BPPP. Sumber data lain yang telah digunakan ialah hasil-hasil penelitian yang dipublikasikan melalui buku dan jurnal. Data dikumpulkan dengan teknik dokumentasi dan dianalisis dengan metode kualitatif dengan teknik interpretasi. Hasil analisis data disajikan secara deskriptif.

\section{HASIL PENELITIAN DAN PEMBAHASAN}

\section{Perjanjian Kawin dalam Perkawinan Campuran}

Undang-Undang Nomor 1 Tahun 1974 tentang Perkawinan, khususnya Pasal 2 Ayat (1) dan (2) menjadi dasar syarat-syarat sahnya suatu perkawinan tidak hanya perkawinan antar sesama WNI tetapi juga perkawinan campuran, yaitu sah menurut hukum masing-masing agama dan kepercayaannya, serta menurut peraturan perundang-undangan yang berlaku (Ratnaningsih, 2018: 1). Perkawinan campuran sendiri didefiniskan secara khusus dalam undang-undang yang sama Pasal 57 yang berbunyi:

"Yang dimaksud dengan perkawinan campuran dalam undang-undang ini adalah perkawinan antara dua orang yang ada di Indonesia tunduk pada hukum yang berlainan, karena perbedaan kewarganegaraan dan salah satu pihak berkewarganegaraan Indonesia"

Dalam konsekuensi adanya perkawinan campuran ini, perlu adanya perjanjian kawin. Perjanjian kawin itu sendiri tidak diatur secara tegas dalam Undang-Undang Nomor 1 Tahun 1974 ataupun dalam Kitab Undang-Undang Hukum Perdata, dan tidak secara jelas mengatur batasanbatasannya. Secara umum perjanjian kawin antara perkawinan sesama warga negara Indonesia dan perkawinan campuran tidak memiliki perbedaan yang besar, bahwa perjanjian kawin dalam perkawinan sesama warga negara Indonesia bukan merupakan perjanjian yang wajib dibuat atau suatu keharusan, dikarenakan apabila tidak adanya perjanjian kawin maka berdasarkan Pasal 119 Kitab Undang-Undang Hukum Perdata, mulai saat perkawinan dilangsungkan maka berlaku pula persatuan bulat kekayaan suami dan isteri. Sedangkan, Perjanjian Kawin dalam perkawinan campuran menghadapi situasi yang berbeda dikarenakan adanya perbedaan status kewarganegaraan. Dengan adanya Perjanjian Kawin maka suami/isteri yang berkewarganegaraan Indonesia masih memiliki hak tertinggi dan terpenuh sebagai warga Negara Indonesia, khususnya dalam kepemilikan tanah di wilayah Indonesia ataupun saham di dalam perusahaan yang berstatus PT (Perseroan Terbatas) Indonesia (Rasjid, 2013: 45).

Beberapa ketentuan perubahan setelah adanya Putusan Mahkamah Konstitusi Nomor 69/PUUXIII/2015, menjadi sebuah jawaban bagi pasangan perkawinan campuran yang belum sempat membuat prenuptial agreement, yaitu:

a. Perjanjian kawin dapat dibuat tidak hanya sebelum perkawinan berlangsung tetapi dapat dibuat sepanjang perkawinan.

b. Perjanjian kawin disahkan oleh pegawai pencatat perkawinan atau notaris dengan isinya berlaku juga terhadap pihak ketiga bersangkutan.

c. Perjanjian kawin dapat diubah dan dicabut dengan kesepakatan kedua belah pihak dengan ketentuan tidak merugikan pihak ketiga.

\section{Bentuk-Bentuk Pengelolaan Harta Kekayaan pada Perjanjian Kawin Perkawinan Campuran}

Pengaturan harta kekayaan suami isteri dalam perjanjian kawin dibedakan atas 2 situasi, yaitu harta kekayaan yang diperoleh sebelum perkawinan dan harta kekayaan yang diperoleh pada saat perkawinan berlangsung. Dalam bentuk barang bergerak dan tidak bergerak, serta barang berwujud dan tidak berwujud. Apabila tidak adanya perjanjian kawin, maka harta bawaan yang dibawa sebelum perkawinan berlangsung, dianggap sebagai harta pribadi masing-masing, sedangkan harta yang diperoleh setelah adanya perkawinan akan dianggap sebagai harta bersama dengan hak kepemilikan dibagi dua sama rata. Dengan adanya perjanjian kawin, terjadi penyimpangan atas persatuan harta ini menjadi terpisah yang disesuaikan dengan kesepakatan masing-masing pihak.

Bentuk-bentuk perjanjian kawin yan akan menetukan bagaimana harta kekayaan dikelola saat perkawinan terjadi (Gunadi, 2018: 137-142):

a. Tidak adanya persekutuan harta benda sama sekali, yakni pemisahan masing-masing harta kekayaan secara terpisah sama sekali, sehingga hanya dikenal dua macam harta kekayaan, yaitu 
harta kekayaan isteri dan harta kekayaan suami. Apabila adanya hutang maka akan ditanggung masing-masing dengan jaminan harta kekayaan pribadi sendiri.

b. Pemisahan harta kekayaan dengan persekutuan hasil pendapat, membedakan kekayaan menjadi 3 jenis, yaitu harta suami, harta isteri, dan harta kekayaan dari hasil pendapatan bersama. Sehingga dalam hal ini, apabila ada hutang dengan jaminan harta kekayaan hasil pendapatan bersama, maka isteri hanya turut memikul kerugian dari bagian keuntungannya saja.

c. Pemisahan harta dengan persekutuan untung rugi. Perjanjian kawin dengan pemisahan harta ini juga membagi harta dalam 3 jenis, harta suami, harta isteri, dan harta kekayaan untung rugi. Apabila tidak secara khusus disebutkan maka perjanjian kawin dianggap terpisah sama sekali.

Dalam hal perjanjian kawin dalam perkawinan campuran, perjanjian kawin dibuat dengan pemisahan harta benda sama sekali sehingga apabila dalam pembelian barang atau properti menggunakan nama dari pasangan warga negara Indonesia maka harta benda tersebut menjadi harta milik pribadi dari warga negara Indonesia tersebut secara penuh.

\section{Perlindungan Hukum Bagi Kreditur Bank Pada Perjanjian Kawin}

Adanya perjanjian kawin antara suami dan isteri menimbulkan akibat hukum, tidak hanya mengikat pihak suami dan isteri tersebut, tetapi juga mengikat pihak ketiga yang berkepentingan. Apabila terjadi perubahan perjanjian, maka tidak boleh merugikan pihak ketiga. Kreditur Bank sebagai pihak ketiga dalam kasus ini, wajib mengetahui bagaimana kedudukan harta kekayaan suami-isteri dengan kaitannya dengan kepastian terlunasinya piutang. Oleh karena itu, perjanjian kawin memiliki peran yang sangat penting untuk memposisikan harta kekayaan yang dimiliki suami isteri sebagai jaminan pelunasan bersama atau terpisah.

Dalam kaitannya dengan perlindungan hukum preventif dalam perjanjian kawin bagi kreditur bank, kreditur bank perlu memperhatikan keabsahan dari perjanjian kawin dan bentuk perjanjian kawin yang dibuat untuk menentukan status harta kekayaan suami-isteri tersebut. Keabsahan dari perjanjian kawin dapat dilihat dari unsur-unsur perjanjian kawin (Jeanita, 2013: 47-78):

a. Dibuat oleh (calon) suami dan (calon) isteri.

b. Dibuat secara tertulis dalam bentuk akta otentik.

c. Tidak melanggar unsur kesusilaan dan ketertiban umum.

d. Unsur tidak boleh dirubah namun dapat dirubah atau dibatalkan selama tidak merugikan pihak ketiga.

Unsur ke empat poin (d) menjadi dilema bagi pihak ketiga apabila tidak ada itikad baik dari pihak debitur dalam menginformasikan perubahan atau pembatalan. Namun berdasarkan Putusan Mahkamah Konstitusi Nomor 69/PUU-XIII/2015, apabila ternyata terbukti pihak kreditur bank dirugikan atas perbuatan mereka, maka perubahan perjanjian kawin tersebut dapat dibatalkan atau digugat ke pengadilan, dan perjanjian tersebut tetap berlaku penuh bagi pihak kreditur bank.

\section{Akibat Hukum Kredit Bermasalah terhadap Harta Benda dalam Perkawinan Campuran dengan Perjanjian Kawin Bila Debitur Wanprestasi}

Kriteria kredit bermasalah bagi debitur yang wanprestasi menurut hukum perikatan dan wanprestasi menurut hukum perbankan mempunyai makna yang berbeda (Jeanita, 2013: 199-200). Menurut hukum perikatan, dikatakan debitur melakukan wanprestasi apabila debitur:

a. Tidak memenuhi prestasi sama sekali;

b. Memenuhi prestasi tetapi tidak sesuai dengan yang diperjanjikan;

c. Terlambat memenuhi prestasi;

d. Melakukan perbuatan yang tidak diperbolehkan dalam perjanjian.

Sedangkan wanprestasi dalam hukum perbankan diatur pada Pasal 31 Peraturan Bank Indonesia Nomor 14/15/PBI/2012 bahwa debitur dinyatakan wanprestasi apabila:

a. Terjadi tunggakan pokok dan/atau bunga dan/atau tagihan lainnya selama 90 (sembilan puluh) hari walaupun asset produktif belum jatuh tempo;

b. Tidak diterimanya pembayaran pokok dan/atau bunga dan/atau tagihan lainnya pada saat asset produktif jatuh tempo; atau c. Tidak dipenuhinya persyaratan lainnya selain pembayaran pokok dan/atau bunga yang dapat mengakibatkan terjadinya wanprestasi.

Oleh karena itu, berdasarkan pemberian kredit dari pihak kreditur bank ke debitur akan mengacu secara khusus pada Peraturan Bank Indonesia sehingga yang dimaksud kredit bermasalah 
adalah kredit yang kualitasnya mulai masuk dalam golongan: kredit kurang lancar, diragukan, dan macet. Di dalam golongan ini debitur dianggap telah melakukan wanprestasi.

Dalam hal debitur telah melakukan wanprestasi, maka jaminan dari debitur dapat digunakan untuk melunasi kekurangan dari pembayaran yang seharusnya dibayarkan oleh pihak debitur. Pihak bank perlu memastikan secara jelas dan benar bentuk perjanjian kawin yang dibuat oleh pasangan perkawinan campuran sebelum menandatangani perjanjian kredit bank. Sedangkan dalam penyelesaian kredit bermasalah berdasarkan waktu pembuatan perjanjian kawin dalam perkawinan campuran, maka dapat dibedakan perjanjian kawin yang dibuat sebelum dan sesudah perkawinan berlangsung:

a. Perjanjian kredit yang dibuat sebelum perkawinan merupakan hutang yang ditanggung masing-masing pihak. Sehingga debitur dianggap menjaminkan harta benda pribadi yang dimilikinya sebelum perkawinan berlangsung sehingga yang dapat diambil oleh pihak kreditur bank apabila debitur wanprestasi tanpa persetujuan dari pasangannya.

b. Perjanjian kredit yang dibuat sesudah perkawinan namun belum ada perjanjian kawin, maka pihak kreditur bank wajib untuk meminta perjanjian kawin yang sudah disahkan oleh pegawai pencatat perkawinan atau notaris terlebih dahulu untuk mendapatkan kepastian jaminan kebendaan.

c. Perjanjian kredit yang dibuat sesudah perkawinan dan adanya perjanjian kawin, maka terjadi pemisahan harta benda yang mana debitur dapat menjaminkan harta kekayaan pribadinya yang telah masuk dalam daftar kekayaan masing-masing pihak sehingga pada saat debitur wanprestasi, pihak kreditur bank dapat menuntut jaminan kebendaan tersebut tanpa merugikan harta kekayaan milik pasangan debitur.

d. Perjanjian kredit yang dibuat sesudah perkawinan dan adanya perjanjian kawin dengan perubahan/pembatalan, maka isi perubahan perjanjian kawin tidak boleh bertentangan dengan perjanjian kredit dengan bank termasuk jaminan kebendaannya. Apabila dikemudian hari perubahan atau pembatalan perjanjian kawin tersebut terbukti merugikan pihak kreditur bank atau tanpa sepengetahuan pihak kreditur bank maka kreditur bank dapat menggugat perubahan/pembatalan perjanjian kawin tersebut dan tetap dapat mengeksekusi jaminan kebendaan debitur apabila debitur melakukan wanprestasi.

Walaupun setelah mengetahui adanya perjanjian kawin berdasarkan bentuk maupun waktu dibuatnya perjanjian kawin, peraturan mengenai pelunasan dan pertanggungjawaban terhadap utangutang yang lahir dari suami dan istri, baik sebelum perkawinan maupun selama perkawinan berlangsung tidak diatur secara terperinci dalam Undang-Undang Nomor 1 Tahun 1974, demikian pula tidak ada pasal-pasal yang khusus mengatur mengenai tanggung jawab atas utang pribadi maupun utang bersama. Dengan demikian dalam Undang-Undang Nomor 1 Tahun 1074 tentang Perkawinan, masalah tanggung jawab suami istri terkait pelunasan utang harus dibedakan juga ke dalam tanggung jawab internal antara suami dan istri serta tanggung jawab eksternal terhadap pihak ketiga atau kreditur bank. Sehingga suami maupun istri bertanggung jawab sendiri atas hutanghutang pribadinya (Putri dkk., 2018: 114- 115) .

\section{Perlindungan Hukum Bagi Kreditur Bank Dalam Menyelesaikan Kredit Bermasalah}

Perlindungan hukum preventif yang telah dibahas pada bab sebelumnya bagi kreditur bank dalam perjanjian kawin adalah dengan wujud pengesahan oleh pegawai pencatat perkawinan atau notaris. Apabila di kemudian hari terjadi sengketa yang dikarenakan kealpaan pihak debitur dalam melakukan pengesahan perjanjian kawinnya dan menyebabkan kerugian bagi pihak kreditur bank dalam penyelesaian kredit bermasalah, maka pihak kreditur bank dapat meminta perlindungan hukum secara represif yaitu pengajuan gugatan ke pengadilan.

Walaupun demikian, kredit bermasalah sendiri dapat diatasi dengan dua strategi, antara lain (Hermansyah, 2014: 75-77):

a. Penyelamatan kredit, adalah suatu langkah penyelesaian kredit bermasalah melalui perundingan kembali antara bank sebagai kreditur dan nasabah peminjam sebagai debitur. Langkah penyelamatannya dengan cara rescheduling atau penjadwalan kembali, reconditioning atau persyaratan kembali, dan restructuring atau penataan kembali, sesuai dengan Surat Edaran Bank Indonesia Nomor 26/4/BPPP.

b. Penyelesaian kredit, adalah suatu langkah penyelesaian kredit bermasalah melalui lembaga hukum apabila upaya penyelamatan kredit bermasalah terakhir melalui restructuring tidak efektif. 
Lembaga hukum tersebut dapat berupa Panitia Urusan Piutang Negara (PUPN) dan Direktorat Jenderal Piutang dan Lelang Negara (DJPLN), melalui litigasi yaitu badan peradilan, dan melalui non-litigasi yaitu arbitrase atau badan alternatif penyelesaian sengketa.

\section{SIMPULAN DAN SARAN}

1. Simpulan

Berdasarkan rumusan sebelumnya, dapat ditarik simpulan bahwa:

a. Berdasarkan ketentuanPasal 29 Undang-Undang Nomor 1 Tahun 1975 tentang Perkawinan, telah jelas dicantumkan perlindungan hukum bagi pihak ketiga secara spesifik, yaitu:

1) Ayat (1), perjanjian kawin merupakan perjanjian tertulis yang disahkan oleh pegawai pencatat perkawinan atau notaris yang dibuat pada waktu atau sebelum perkawinan berlangsung atau selama perkawinan dilangsungkan dan isinya berlaku juga terhadap pihak ketiga tersangkut. Artinya bahwa sebelum melakukan perjanjian kredit, pihak bank sebagai pihak ketiga harus mengecek ada tidaknya perjanjian kawin serta keabsahan dari perjanjian kawin tersebut baik dari segi isi dan bentuk perjanjian kawin, jenis akta otentik atau bawah tangan, dan pengesahan perjanjian kawin itu sendiri. Dengan adanya perjanjian kawin ini dapat memperjelas status harta benda suami isteri yang akan dijaminkan kepada kreditur bank sebagai jaminan pellunasan di kemudian hari bila diperlukan.

2) Ayat (4), apabila terjadi perubahan atau pencabutan perjanjian kawin maka perubahan atau pencabutan tersebut tidak merugikan pihak ketiga. Perubahan atau pencabutan perjanjian kawin yang merugikan pihak kreditur bank ataupun tanpa sepengetahuan pihak kreditur bank sebagai pihak ketiga merupakan bukti adanya itikad tidak baik dari pihak debitur sehingga pihak kreditur bank dapat menuntut pembatalan perubahan atau pencabutan perjanjian kawin tersebut.

Perlindungan hukum preventif bagi kreditur bank dalam perjanjian kawin adalah dengan wujud pengesahan oleh pegawai pencatat perkawinan atau notaris. Apabila di kemudian hari terjadi sengketa yang dikarenakan kealpaan pihak debitur dalam melakukan pengesahan perjanjian kawinnya dan menyebabkan kerugian bagi pihak kreditur bank atau adanya itikad tidak baik dalam perubahan atau pencabutan perjanjian kawin, maka pihak kreditur bank dapat meminta perlindungan hukum secara represif yaitu pengajuan gugatan ke pengadilan.

b. Akibat hukum bagi harta benda suami atau istri untuk kreditur bank apabila debitur yang terikat dalam perkawinan campuran tersebut wanprestasi tergantung dari bentuk perjanjian kawin yang dibuat. Suami atau isteri yang berkewarganegaraan Indonesia sebagai debitur dapat memberi jaminan kebendaan dari harta kekayaannya secara bebas dan dapat diambil sebagai jaminan pelunasan oleh pihak kreditur bank apabila debitur tersebut wanprestasi. Walaupun demikian, masalah tanggung jawab suami istri terkait pelunasan utang harus dibedakan juga ke dalam tanggung jawab internal antara suami istri sehingga tidak kaku bahwa hutang-hutang tersebut merupakan tanggung jawab pribadi salah satu pihak saja, dikarenakan bisa jadi hutang yang dibuat merupakan hutang untuk kebutuhan rumah tangga atau kepentingan bersama suami dan isteri beserta anak bila ada.

\section{Saran}

Adapun saran-saran dari pembahasan ini adalah:

a. Belum adanya definisi yang jelas untuk memberikan batasan waktu perjanjian perkawinandibuat. Sehingga pelaku perkawinan campuran bisa saja menunda-nunda pembuatan perjanjian kawin sampai pada saat perjanjian kawin itu dibutuhkan. Oleh karena itu perlu adanya aturan yang memperjelas kembali kapan batas waktu maksimum pembuatan perjanjian kawin setelah perkawinan berlangsung sampai ke pengesahannya dengan sanksi yg tegas apabila tidak adanya perjanjian kawin dalam batasan waktu tertentu itu. Namun di sisi yang lain bisa jadi tidak dibuatnya perjanjian kawin dikarenakan tidak adanya pengetahuan hukum mengenai perjanjian kawin itu sendiri sehingga perlu adanya sosialisasi dari pihak pemerintah terlebih dahulu sebelum menetapkan aturan baru untuk meningkatkan kesadaran para pelaku perkawinan campuran untuk membuat perjanjian kawin. 
b. Bagi pelaku perkawinan campuran yang telah memiliki perjanjian kawin atau merencanakan membuat perjanjian kawin, perlu membuat daftar/inventaris harta kekayaan yang lebih terperinci bagi masing-masing pihak yang dilampirkan dalam perjanjian kawin. Hal ini bertujuan untuk memperjelas status harta benda yang dimiliki sehingga tidak ada salah interpretasi bagi kedua belah pihak ataupun pihak ketiga yang tersangkut di kemudian hari. Apabila terjadi perubahan atau pembatalan perjanjian kawin, maka pihak ketiga yang terkait perlu diinformasikan dan isi perubahan tidak merugikan pihak ketiga tersebut untuk mencegah adanya tuntutan hukum.

\section{DAFTAR PUSTAKA}

Gunadi. (2018). Perjanjian Perkawinan Menurut Kitab Undang-Undang Hukum Perdata dan UndangUndang Nomor 1 Tahun 1974. Al-Afkar Journal for Islamic Studies, 1(1), 120-148.

Hariss, A., \& Kasmara, N. W. (2019). Tinjauan Yuridis Akibat Hukum Perjanjian Harta Bersama yang Dibuat oleh Suami Istri Setelah Perkawinan berdasarkan Putusan Mahkamah Konstitusi Nomor 69/PUU-XIII/2015. Wajah Hukum, 3(1), 65-73.

Hermansyah. (2014). Hukum Perbankan Nasional Indonesia. Prenadamedia Group.

Istrianty, A., \& Priambada, E. (2015). Akibat Hukum terhadap Perjanjian Perkawinan yang Dibuat Setelah Perkawinan Berlangsung. Privat Law, 3(2), 84-92.

Jeanita, A. (2013). Status Hukum Perjanjian Kawin berdasarkan Kitab Undang-Undang Hukum Perdata dan Undang-Undang Perkawinan. Universitas Indonesia.

Kusuma, R. W. (2010). Pembuatan Perjanjian Kawin Setelah Perkawinan dan Akibat Hukumnya terhadap Pihak Ketiga (Studi Kasus Penetapan Pengadilan Negeri Jakarta Timur Nomor. 207/Pdt.P/2005/PN.Jkt.Tmr dan Penetapan Pengadilan Negeri Nomor.459/Pdt.P/2007/PN.Jkt.Tmr). Universitas Diponegoro.

Putri, P. Y., Djatmika, P., \& Puspitawati, D. (2018). Implikasi Yuridis Perjanjian Perkawinan Yang Dibuat Selama Dalam Ikatan Perkawinan Terhadap Utang Bersama Pasca Putusan Mahkamah Konstitusi Nomor 69/Puu-Xiii/2015. Legality, 26(1), 95-117.

Rasjid, I. (2013). Tinjauan Perjanjian Perkawinan terhadap Perkawinan Campuran Warga Negara Indonesia-Warga Negara Australia yang Dilangsungkan di New South Wales-Australia. Universitas Indonesia.

Ratnaningsih, E. (2018). Perkawinan Campuran Antara WNI dan WNA di Indonesia. Universitas Binus.

Situmeang, P. (2019). Implikasi Perjanjian Kawin terhadap Harta dalam Perkawinan Campur. Recital Review, 1(2), 117-131. 